\title{
Indonesia Global Value Chain Participation in Regional Comprehensive Economic Partnership (RCEP)
}

\author{
Steven Raja Ingot \\ Trade Analysis and Development Agency \\ Ministry of Trade, Republic of Indonesia \\ Jakarta, Indonesia \\ sri.bako@gmail.com
}

\author{
Dian Dwi Laksani \\ Trade Analysis and Development Agency \\ Ministry of Trade, Republic of Indonesia \\ Jakarta, Indonesia \\ dian.laksani@yahoo.com
}

\begin{abstract}
The Global Value Chain (GVC) has proved to be an important factor that encouraged trade in the last 30 years. Cooperation within the RCEP can facilitate Indonesian trade as an effort to increase value added within global value chain framework. Economic cooperation is proven as a way to boost GVC participation within its member in the region, including the Regional Comprehensive Economic Partnership (RCEP) due to regulation uniformity. The study used Descriptive Qualitative statisctics and Trade in Value Added (TiVA) data aims to identify Indonesias GVC participation within RCEP as well as its position in GVC participation. Specifically, this study uses the participation index, the index of the number of production stages and index of the distance of the final product. The study shows that Indonesias GVC participation is higher than neighboring countries such as Malaysia and Thailand however, compared to other East Asian countries Indonesia is still low. Most of Indonesias GVC participation is as a supplier of raw material. Within RCEP, Indonesias participation in GVC is still dominated by Low Technology Industries. To maximize Indonesia GVC participation within RCEP and boost trade, public-private cooperation and predictable trade, as well as investment climate reforms, is required.
\end{abstract}

\section{Keywords-RCEP, GVC, Trade in Value Added}

\section{INTRODUCTION}

The ASEAN Regional Comprehensive Economic Partnership (RCEP) is a free trade agreement between ASEAN countries and FTA Partners, which involves 16 countries, forms $45 \%$ of the world's total population and contributes to one third of world GDP in total. The main destination Indonesian exporters in the RCEP region namely China, Japan, India, Singapore, Malaysia and Thailand. RCEP itself is considered able to increase competitiveness for Indonesia where, based on 2011 data, Indonesia's export contribution to GDP is only $20 \%$, compared to Malaysia (79.3\%), Thailand (66.2\%), and Singapore $(157.6 \%)$ and give Indonesia greater market access opportunities with uniform rules, with the existence of a uniform Rules of Origin will encourage the growth of domestic industries and by utilizing efficient supply chains Indonesia will become part of a global value chain.
The Indonesian government itself is very confident that this global value chain $(\mathrm{GVC})$ is able to increase the comparative advantage of superior export commodities. GVC is a production system revolution in the 21 st century where production and distribution of goods are held jointly by several countries. In GVC, one production stage from a single production process unit is held in one country while the next stage is carried out in another country. GVC tends to increase with the communication and logistics technology revolution [1]. Indonesia currently has developed 10 main commodities, among others: textiles and textile products, electronics, rubber and rubber products, palm oil, forest products, footwear, automotive, shrimp, cocoa and coffee. In addition, Indonesia has 10 potential commodities which are also in demand by international markets, such as: leather products, medical equipment, medicinal plants, processed foods, essential oils, fish and fishery products, crafts, jewelry, spices and office equipment [2]. So that the global value chain concept is very important as a basis for enlarging international trade relations that begins within the framework of RCEP. it is important for the Government of Indonesia to know the level of participation of Indonesia GVC in RCEP so that appropriate policies can be produce to increase GVC Indonesia's participation in RCEP in the future.

\section{RESEARCH METHOdOLOGY}

The study used Descriptive Qualitative statistics analysing trade data and Trade in Value Added (TiVA) data that aims to identify Indonesias GVC participation within RCEP as well as its position in GVC participation. According to Ahmad [3] what is meant by TiVA (Trade in Value-Added) measures how much value a country adds in the production of exported goods or services. GVC participation is measured by the amount of foreign value in export or import and the amount of domestic value added in other country export/import.. Sectoral Value Added Trade can be measured through the Input-Output (Leontief) [4] Table of all related economic activities, namely as input providers or as output users. The concepts are as follows [5]: 


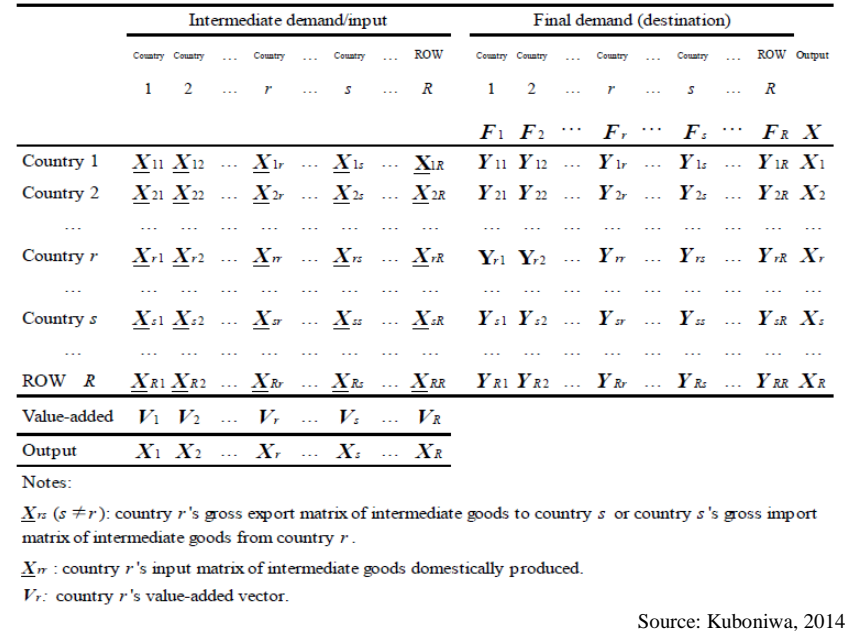

Fig. 1. Data structure of an international input-output table

The sectors in IO table could be regarded as nodes while inter-sector value stream contributes to weighted and directed edges in the construction of network model. In consideration of both availability and authority, IO table is definitely the priority-first data source to establish mathematics model, e.g., it can show flows of final and intermediate goods and services. In addition, it is provided in a matrix, which can be directly or with minor modification adopted as adjacency matrix in establishing weighted and directed network.

\section{RESULT AND DISCUSSION}

Trade in Value Added (TiVA) is used to analyse Indonesia's Role in the global value chain within the scope of RCEP. Trade in Value Added (TiVA) calculates the added value of goods between changes to new items (e.g. final goods). For example the process of assembling a car will produce final goods, where the goods between all components are worth $\$ 12,000$, the production process is to assemble components into $\$ 2,000$ worth of cars, and the value of new items in the form of a car is $\$ 14,000$. Then it can be calculated the added value of a car is $\$ 14,000$ - \$ $12,000=\$ 2,000$. Value added calculation provides information about (1) production factor income, (2) production technology (labor intensive or capital intensive), (3) the number of production factors used.

Based on Intra RCEP trade data it is known that China is the main exporter in the RCEP region with an export value of USD 696.58 Billion followed by Japan at USD 340.99 Billion and the Republic of Korea at USD 319.42 Billion. Whereas compared to the RCEP country in the ASEAN region, the value of Indonesia's exports amounted to USD 114.41 Billion, below Malaysia, Thailand, Vietnam.

TABLE I. INTRA RCEP EXPORTING COUNTRY

Unit: US Dollar Billion
\begin{tabular}{|c|l|r|r|r|}
\hline \multirow{2}{*}{ No } & \multirow{2}{*}{ Exporters } & \multicolumn{3}{|c|}{ Tahun } \\
\cline { 2 - 5 } & & $\mathbf{2 0 1 6}$ & \multicolumn{1}{c|}{$\mathbf{2 0 1 7}$} & \multicolumn{1}{c|}{$\mathbf{2 0 1 8}$} \\
\cline { 2 - 5 } & RCEP Aggregation & $1,907.00$ & $2,195.00$ & $2,424.51$ \\
\hline 1 & China & 571.23 & 625.10 & 696.58 \\
\hline 2 & Japan & 279.10 & 318.41 & 340.99 \\
\hline 3 & Korea, Republic of & 242.95 & 299.83 & 319.42 \\
\hline 4 & Singapore & 191.45 & 216.22 & 232.40 \\
\hline 5 & Australia & 133.40 & 141.55 & 154.95 \\
\hline 6 & Malaysia & 114.10 & 132.11 & 148.27 \\
\hline 7 & Thailand & 114.72 & 129.95 & 142.23 \\
\hline 8 & Viet Nam & 70.93 & 95.49 & 138.20 \\
\hline 9 & Indonesia & 86.14 & 104.55 & 114.41 \\
\hline 10 & India & 44.71 & 59.94 & 64.90 \\
\hline 11 & Philippines & 29.20 & 34.39 & 32.54 \\
\hline 12 & New Zealand & 19.20 & 22.42 & 24.06 \\
\hline 13 & Brunei Darussalam & 4.46 & 5.17 & 5.99 \\
\hline 14 & Lao People's Democratic Republic & 2.83 & 4.68 & 4.93 \\
\hline 15 & Cambodia & 2.60 & 5.19 & 4.65 \\
\hline
\end{tabular}

Source: Trademap, 2019

From Indonesia's export data (Table II) the Top 5 exported products of Indonesia to the RCEP region are Palm Oil (HS 151190), Copper ores and Concentrates (HS 260300), Crude Palm Oil (HS 151110), Semi Bleached or Bleached non coniferous chemical wood pulp, soda or sulphate... (HS 470329), Gold incl Gold plated with Platinum, unwrought for non monetary purposes (HS 710812) followed by rubber, ferro-nickel, fatty acid, copper etc.

TABLE II. INDONESIA EXPORT PRODUCT TO RCEP

\begin{tabular}{|c|c|c|c|c|c|}
\hline \multirow{2}{*}{ No } & \multirow{2}{*}{ HS Code } & \multirow{2}{*}{ Description } & \multicolumn{3}{|c|}{ Year } \\
\hline & & & 2016 & 2017 & 2018 \\
\hline & 'TOTAL & All products & $86,141.28$ & $104,551.85$ & $114,406.40$ \\
\hline 1 & '151190 & $\begin{array}{l}\text { Palm oil and its fractions, whether or not refined } \\
\text { (excluding chemically modified and crude) }\end{array}$ & $4,114.27$ & 4.979 .09 & $4,771.72$ \\
\hline 2 & '260300 & Copper ores and concentrates & $3,427.34$ & $3,439.60$ & $3,512.32$ \\
\hline 3 & '151110 & Crude palm oil & $2,333.87$ & $3,604.08$ & $2,635.36$ \\
\hline 4 & '470329 & $\begin{array}{l}\text { Semi-bleached or bleached non-coniferous chemical } \\
\text { wood pulp, soda or sulphate (excluding dissolving ... }\end{array}$ & $1,307.38$ & $2,016.74$ & $2,201.49$ \\
\hline 5 & '710812 & $\begin{array}{l}\text { Gold, incl. gold plated with platinum, unwrought, for non- } \\
\text { monetary purposes (excluding gold ... }\end{array}$ & 991.76 & $1,614.62$ & $1,747.49$ \\
\hline 6 & '400122 & Technically specified natural rubber "TSNR" & $1,476.00$ & $2,390.44$ & $1,699.54$ \\
\hline 7 & '711299 & $\begin{array}{l}\text { Waste and scrap of silver, incl. metal clad with silver, and } \\
\text { other waste and scrap containing ... }\end{array}$ & 719.94 & 905.72 & $1,382.54$ \\
\hline 8 & '720260 & Ferro-nickel & 563.70 & $1,295.82$ & $1,251.60$ \\
\hline 9 & '441231 & $\begin{array}{l}\text { Plywood consisting solely of sheets of wood }<=6 \mathrm{~mm} \\
\text { thick, with at least one outer ply of tropical } . . .\end{array}$ & 642.25 & 738.24 & $1,016.19$ \\
\hline 10 & '800110 & Unwrought tin, not alloyed & 789.18 & $1,016.85$ & 993.31 \\
\hline 11 & '382319 & $\begin{array}{l}\text { Fatty acids, industrial, monocarboxylic; acid oils from } \\
\text { refining (excluding stearic acid, oleic ... }\end{array}$ & $1,029.92$ & $1,106.37$ & 988.01 \\
\hline 12 & '740311 & $\begin{array}{l}\text { Copper, refined, in the form of cathodes and sections of } \\
\text { cathodes }\end{array}$ & 736.56 & $1,029.20$ & 962.82 \\
\hline 13 & '871120 & $\begin{array}{l}\text { Motorcycles, incl. mopeds, with reciprocating internal } \\
\text { combustion piston engine of a cylinder ... }\end{array}$ & 317.57 & 504.84 & 880.67 \\
\hline 14 & '854430 & $\begin{array}{l}\text { Ignition wiring sets and other wiring sets for vehicles, } \\
\text { aircraft or ships }\end{array}$ & 664.40 & 795.57 & 878.98 \\
\hline 15 & '870322 & $\begin{array}{l}\text { Motor cars and other motor vehicles principally designed } \\
\text { for the transport of persons, incl. ... }\end{array}$ & 639.59 & 587.79 & 875.06 \\
\hline
\end{tabular}


From the Table, most of these products are raw materials that are going to be used as inputs for countries in the RCEP region. One example is the product Crude palm oil.

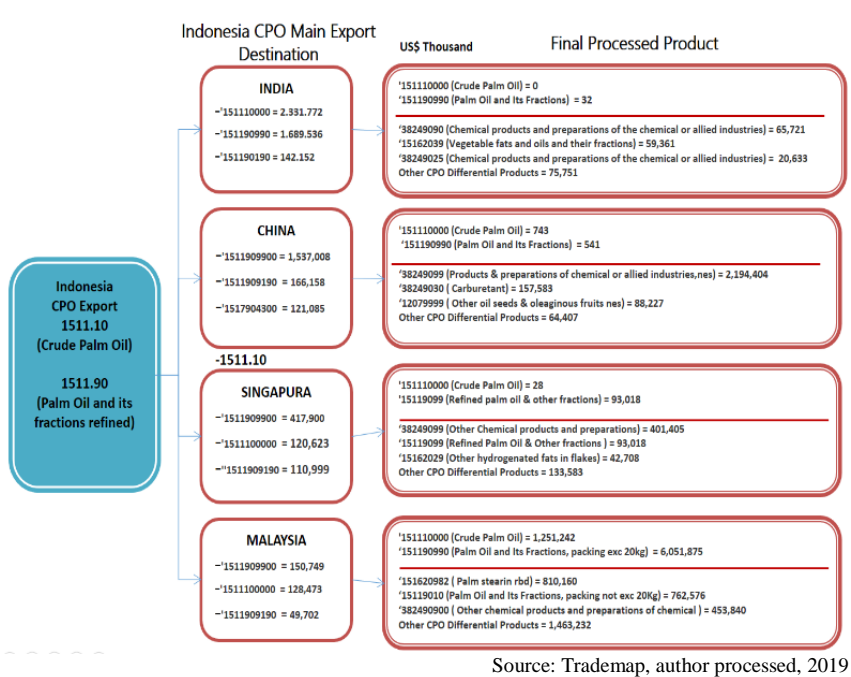

Fig. 2. Indonesias CPO Export Destination Country and the Processed Product

Indonesia exports CPO to India, China, Singapore, Malaysia then they processed and exported to all countries in the world. The involvement of Indonesia in the global value chain (GVC) is limited to supplying raw material, is undeniable because Indonesia has a very large reserve of natural resources.

Then, we could also see how the government should take advantage of the opportunities so that industry in Indonesia can participate in global value chains within the region. Therefore it is relevant to see the index of forward and backward linkages in aggregate within the scope of the region, such as ASEAN and RCEP.



Fig. 3. Domestic and Foreign Value added in Export - RCEP

From the data in Figure 3 it appears that Indonesia has more domestic value added. Indonesia's involvement in the RCEP tend to Forward Linkages [6]. Indonesia's participation is more as a supplier (forward) not as a user/ processor.
TABLE III. PERCENTAGE OF EXPORT OF INTERMEDIATE AND FINAL GOODS TO RCEP

\begin{tabular}{|ccccccc}
\hline Country & \multicolumn{3}{c}{$\begin{array}{c}\text { Gross exports } \\
\text { of } \text { intermediate }\end{array}$} & \multicolumn{3}{c}{$\begin{array}{c}\text { Gross exports of final } \\
\text { demand }\end{array}$} \\
& \multicolumn{3}{c}{ Year } & \multicolumn{3}{c}{ Year } \\
& $\mathbf{2 0 0 9}$ & $\mathbf{2 0 1 0}$ & $\mathbf{2 0 1 1}$ & $\mathbf{2 0 0 9}$ & $\mathbf{2 0 1 0}$ & $\mathbf{2 0 1 1}$ \\
\hline Australia & $80 \%$ & $83 \%$ & $83 \%$ & $20 \%$ & $17 \%$ & $17 \%$ \\
Japan & $76 \%$ & $74 \%$ & $74 \%$ & $24 \%$ & $26 \%$ & $26 \%$ \\
Korea & $75 \%$ & $75 \%$ & $74 \%$ & $25 \%$ & $25 \%$ & $26 \%$ \\
New Zealand & $58 \%$ & $60 \%$ & $58 \%$ & $42 \%$ & $40 \%$ & $42 \%$ \\
Brunei Darussalam & $94 \%$ & $93 \%$ & $93 \%$ & $6 \%$ & $7 \%$ & $7 \%$ \\
Cambodia & $65 \%$ & $62 \%$ & $63 \%$ & $35 \%$ & $38 \%$ & $37 \%$ \\
China (People's & $59 \%$ & $61 \%$ & $61 \%$ & $41 \%$ & $39 \%$ & $39 \%$ \\
Republic of) & $73 \%$ & $75 \%$ & $73 \%$ & $27 \%$ & $25 \%$ & $27 \%$ \\
India & $73 \%$ & & & \\
Indonesia & $\mathbf{8 0 \%}$ & $\mathbf{7 9 \%}$ & $\mathbf{7 9 \%}$ & $\mathbf{2 0 \%}$ & $\mathbf{2 1 \%}$ & $\mathbf{2 1 \%}$ \\
Malaysia & $71 \%$ & $70 \%$ & $71 \%$ & $29 \%$ & $30 \%$ & $29 \%$ \\
Philippines & $74 \%$ & $74 \%$ & $72 \%$ & $26 \%$ & $26 \%$ & $28 \%$ \\
Singapore & $68 \%$ & $68 \%$ & $67 \%$ & $32 \%$ & $32 \%$ & $33 \%$ \\
Thailand & $64 \%$ & $64 \%$ & $63 \%$ & $36 \%$ & $36 \%$ & $37 \%$ \\
Viet Nam & $68 \%$ & $67 \%$ & $67 \%$ & $32 \%$ & $33 \%$ & $33 \%$ \\
\hline
\end{tabular}

The table shows that when compared with other RCEP countries, the percentage of Indonesia's intermediate exports is $79 \%$ percent, which is higher than other ASEAN countries such as Malaysia, Philipines, Singapore and Thailand. The statistics in the above table shows gross export, not trade in value added. It is the amount of foreign value added in a country's export and the amount of domestic value added in other country export that determines the extent of GVC participation.



Fig.4. Indonesian Export Product Composition to RCEP by Type of Industry

In more detail, Table IV presents Key Sector in the main Country of RCEP. This key sector is the main sector for every country in trade relations [7] because it is a sector that plays an important role in the region and has high competitiveness. Based on table IV, it can be seen that Indonesia's key sectors are similar to other ASEAN countries such as Malaysia, Thailand, the Philippines, Singapore and even other Asian countries. This indicates that Indonesia has compete not only with ASEAN countries but also in Asia on participating in the Global value chain. 
TABLE IV. KEY SECTOR IN THE MAIN COUNTRY OF RCEP

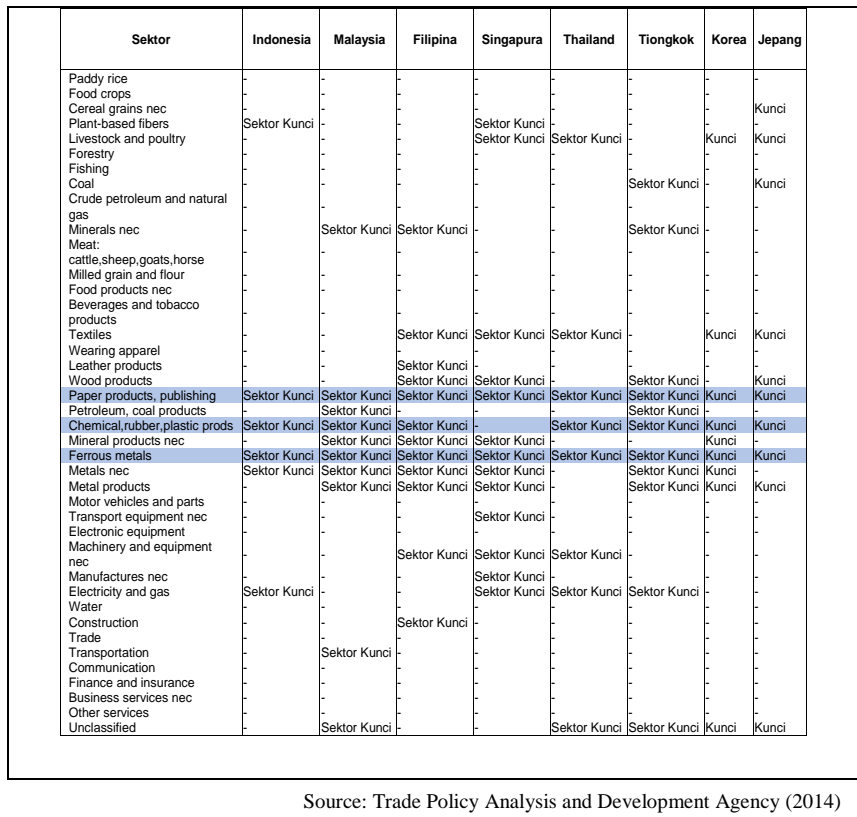

The sectors classified as key sectors are not too many for Indonesia, which are only six sectors and most of them are industrial sectors processing raw materials, such as paper products and publishing, chemical, rubber, and plastic products, ferrous metals, and other metals. In the future, Indonesia needs to deeper integrate within RCEP by strengthening other sectors that will contribute more domestic value added into the supply chain [8].

For the scope of ASEAN, sectors that need to be encouraged by Indonesia are mineral products, metal products, and other machinery and equipment because this sector is a key sector in the ASEAN region. Therefore, if Indonesia can take advantage of this opportunity by participating in this value chain, the domestic industry in that sector will be able to grow due to high demand in the ASEAN region.

Meanwhile, for the RCEP region, the sectors that need to be encouraged in Indonesia are electronics, vehicle, wood products, petroleum and coal products, mineral products, and metal products. These sectors have a high impact on the forward and backward linkage so that it would be good if Indonesia could expand its network in the sector. Another interesting finding is that textiles became a key sector but outside of RCEP and ASEAN. This indicates strong competition in the global value chain for textile products in the country in RCEP and ASEAN. In the ASEAN region, Philippine, Singapore and Thailand textile products participate more in the global value chain compared to Indonesian textile products. While in the RCEP, China and India regions, it is competitive in participating in the global value chain of textile products.

Indonesia needs to improve its position in the global value chain, Government need to support superior local products. Various efforts to improve Indonesia's position not only as an input provider country must be done. Indonesian exports in the form of auxiliary raw materials are mostly dominated by industries that are highly dependent on natural resources (food, tobacco, fuel, chemicals, and the paper industry). The basic metal industry and the petroleum product industry, almost $100 \%$ of their exports are supporting raw materials and low technology industries. Products from the industry are generally not consumer goods and few are capital goods. Efforts that need to be carried out in the context of RCEP are strengthening national policies that are more focused on downstream product value-added programs through increasing machine availability and access to technology needed to accelerate the realization of value-added products. In addition, efforts to create a business climate that encourages investment, especially those that produce superior Indonesian products that are value-added and export-oriented, also need to be done.

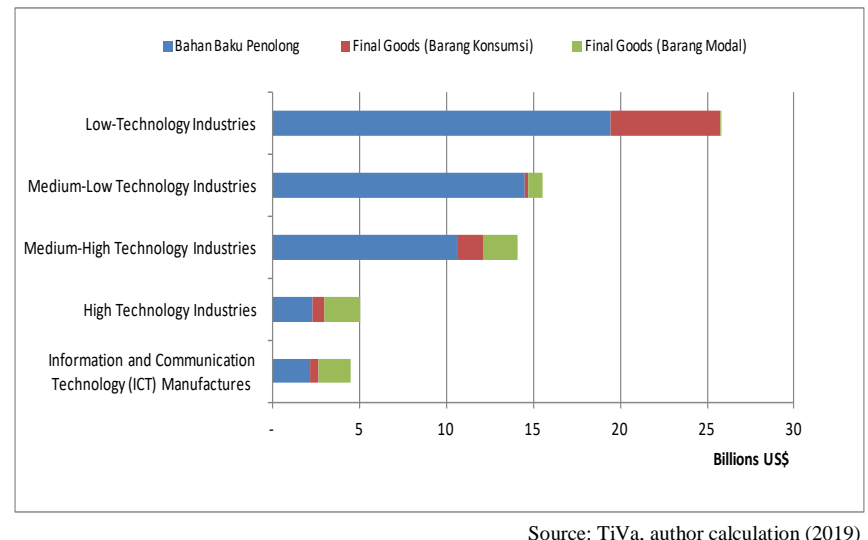

Fig. 5. Indonesian Export Composition to RCEP Based on Technology Group

Indonesia's involvement in GVC in RCEP is still dominated by Low Technololgy Industries which produces raw / auxiliary materials. Industry in this group is labor intensive industry and its raw materials come from natural resources where Indonesia has a comparative advantage as its raw material supplier. The contribution of raw materials that support Hi-Tech and Information and Technology industries is still relatively low (less than US $\$ 5$ billion).

\section{CONCLUSION AND RECOMMENDATION}

Indonesia's participation in the global value chain in the scope of RCEP is still dominated by Low Technology Industries which produces raw / auxiliary materials such as metals and minerals. Industry in this group is a labor intensive industry and its raw materials come from natural resources where Indonesia has a comparative advantage as its raw material supplier.

Then the government should take advantage of opportunities so that sectors in Indonesia can participate in global value chains within the region. In the future, Indonesia needs to strengthen sectors that provide high added value in order to be able to participate in global value chains within the region. Therefore, if Indonesia can take advantage of this opportunity by participating in this value chain, the domestic industry in that sector will be able to grow due to high demand in the ASEAN region.

Efforts that need to be carried out in the context of RCEP are strengthening national policies that are more focused on downstream product value-added programs through increasing machine availability and access to technology needed to accelerate the realization of valueadded products. In addition, efforts to create a business 
climate that encourages investment, especially those that produce superior Indonesian products that are value-added and export-oriented, also need to be done.

\section{REFERENCES}

[1] EU-Indonesia Trade Cooperation Facility, 2015. Accessed from https://ec.europa.eu/europeaid/projects/eu-indonesia-tradecooperation-facility-tcf_en

[2] Trademap, 2019 $2019 . \quad$ Accessed from https://www.trademap.org/Index.aspx

[3] Ahmad, Nadim et.al. 2013. A Three Stage Reconciliation Method to Construct Time Series International Input-Output Database

[4] Xing, L. 2017. Analysis of Inter-country Input-Output Table Based on Citation Network : How to Measure the Competition and Collaboration between Industrial Sectors on the Global Value Chain. PLos ONE $12 \quad$ (9): e0184055. Accessed from https://doi.org/10.1371/journal.pone.0184055

[5] Kuboniwa, Masaaki. 2014. Russia's Global Value Chain using a Modified World Input-Output Data. Japan: Institute of Economic Research Hitotsubashi University

[6] Trade in Value Added (TiVA). 2018. Accessed from https://stats.oecd.org/Index.aspx?datasetcode=TIVA_2018_C1

[7] Ministry of Trade, TREDA, 2014. Analysis Of Potential And Benefits Of RCEP Area Value For Indonesia. [in Indonesian]

[8] Rubinova, Stela. 2017. The Impact of New Regionalism on Global Value Chains Participation. Geneva : CTEI Working Papers. 